\title{
Evaluation of the Variations of Some Traits Among Entries Genotypes of Bread Wheat (Triticum aestivum L.) and Their Relationship with Grain Yield
}

\author{
Salih Hadi Farhood Al-salim ${ }^{1}$, Reem Al-edelbi ${ }^{2}$, Hassin kassar $^{3}$, Hayder Najm Abed ${ }^{4}$ \\ ${ }^{1}$ Ministry of Agriculture, Directorate of Agriculture, Dhi-Qar, AL-Nassiriya, Iraq \\ ${ }^{2}$ Faculty of Agriculture, University of Damascus, Damascus, Syria \\ ${ }^{3}$ Ministry of Agriculture, Al-Moradia Research Station, AL-Hilla, Iraq \\ ${ }^{4}$ Ministry of Agriculture, National Program of Wheat Development in Iraq, Baghdad, Iraq
}

\section{Email address:}

salihalsalim@gmail.com (S. H. F. Al-salim), agro_reem@hotmail.com (R. Al-edelbi)

\section{To cite this article:}

Salih Hadi Farhood Al-salim, Reem Al-edelbi, Hassin kassar, Hayder Najm Abed. Evaluation of the Variations of Some Traits Among Entries Genotypes of Bread Wheat (Triticum aestivum L.) and Their Relationship with Grain Yield. International Journal of Applied Agricultural Sciences. Vol. 1, No. 3, 2015, pp. 79-83. doi: 10.11648/j.ijaas.20150103.16

\begin{abstract}
A field experiment was carried out in Iraq, during the season 2013-2014, in order to evaluate the performance of different ten genotypes of bread wheat in irrigated field conditions, according to the design of randomized complete block in three replications. The results indicated the existence of genetic variability, in a significant manner (at the level 5\%), in the response of the studied genotypes to the conditions of the field for all of the traits such as plant height (cm), number of tillers per plant, number of spikes per unit area, spike length $(\mathrm{cm})$, weight of spikes per stem and thousand grains weight $(\mathrm{g})$. Both Egyptian

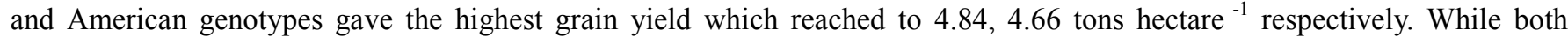
genotypes Apa-99 and Synthetic-10 gave less grain yield 2.62, 2.60 tons hectare $^{-1}$ respectively. The study showed the importance of the number of grains per spike and the thousand grains weight due to their positive and high significant correlation with the grain yield, so it can be used as indicators of suitable selection for the development of high- yielding genotypes.
\end{abstract}

Keywords: Bread Wheat, Genotypes, Correlation, Grain Yield

\section{Introduction}

Bread Wheat (Triticum aestivum L.) is the most important staple crop in the world in terms of the harvested area, production, and nutrition; as it supplies about $19 \%$ of the calories and $21 \%$ of the protein to the world's population (Harlan, 1998, FAO, 2011). The International Food Policy Research Institute (IFPRI) projections indicate that the world demand for wheat will rise to 775 million tons by 2020 and $60 \%$ by 2050 (Rosegrant \& Agcaoili, 2010).

The most important criteria in any crop improvement program is the selection of genotypes with all possible desirable yield contributing traits. Therefore, It is important to investigate the genetic variation of the wheat genotypes in breeding programs (Hawkes, 1977) .Genetic diversity of plants can be identified by several methods such as morphological screening and morphological traits which eventually may result in enhanced food production (Akcura, 2011). According to Mollasadeghi et al., 2012) number of spike per unit area, plant height and grain number showed more genetic variation.

Grain yield is a complex trait which is result of yield components (number of plant per area, number of grain per spike, grain weight) as well as other related traits such as plant height, number of spikelets per spike and other traits and also it is influenced by genotype and agro ecological conditions (Atkinson et al. 2008). The grain yield of wheat is determined by three yield components: productive spikes per unit area, number of grains spike ${ }^{-1}$ and 1000 grain weight (Tian et al., 2012). Correlation analysis provides information about association of plant characters and therefore, leads to a directional model for yield prediction (Ashfaq et al., 2003). The grain yield was significantly and positively correlated with number of spike per square meter (Korkut et al., 2001), plant height (Mohammadi et al., 2012), grains per spike (Babak and Ahmad, 2015) and 1000 grains weight (Khayatnezhad et al., 2010). Shamsi et al. (2011) showed that the most important yield component on grain yield is number of grains per spike followed by number of spikes per unit area 
and 1000 grains weight.

The aims of this research concentrated on evaluating genetic diversity in Bread wheat genotypes in normal irrigation conditions, to define the difference in the morphological and quantity traits between the studied genotypes, to study the correlation between studied traits and to determine the best genotypes to be exploited in breeding programs.

\section{Materials and Methods}

The present investigation was carried out in Iraq during the winter season of 2013-2014 under field irrigated conditions.

\subsection{Plant Material}

This study evaluated 10 diverse bread wheat (Triticum aestivum L.) genotypes which were planted under well-watered conditions. They are: Egypt, Sakha-93, Giza-11, Giza-168, Synthetic10, Synthetic13, Synthetic 38, Bohouth-22, Apa -99 and American. Seeds were obtained from the Gene-Bank of the Office of Agricultural ResearchMinistry of Agriculture in Iraq, International Center for Agricultural Research in Dry Area (ICARDA) and from International Maize and Wheat Improvement Center (CIMMYT). The tested genotypes used in this study are presented in Table 1.

The data were recorded at appropriate time at maturity of ten randomly selected plants of two middle rows in each plot for eight traits as follows: plant height $(\mathrm{PH})$ in $(\mathrm{cm})$; was measured from soil surface to the highest plant tip excluding awns; Number of tillers per plant (NT); Number of Spikes Per Square meter (NS); Spike Length (SL) in (cm); Number of Grains per Spike (NGS); Spikes Weight per stem (SW) in (g); 1000-grains weight (TGW) in (g) measured after final harvest of the plots and grain yield $(\mathrm{GY})$ in $\left(\mathrm{t}^{\mathrm{h}} \mathrm{h}^{-1}\right)$. It was recorded of each experimental plot after harvest on an electronic scale and then converted in to hectare.

Table 1. List of studied wheat genotypes with their origin.

\begin{tabular}{llll}
\hline No of Geno & Name & Row type & Origin \\
\hline G1 & Egypt & W1 & ICARDA \\
G2 & Sakha-93 & W2 & ICARDA \\
G3 & Giza -11 & W3 & ICARDA \\
G4 & Giza -168 & W4 & ICARDA \\
G5 & Synthetic- 10 & W5 & CIMMYT \\
G6 & Synthetic -13 & W6 & CIMMYT \\
G7 & Synthetic -38 & W7 & CIMMYT \\
G8 & Bohouth- 22 & W8 & Iraq \\
G9 & Ipa -99 & W9 & Iraq \\
G10 & American & W10 & CIMMYT \\
\hline
\end{tabular}

\subsection{Experimental Design}

The seeds of ten genotypes were sown in the field area of AL-Graf, which belongs to proviance of Dhi-Qar and far away about $26 \mathrm{~km}$ from north of AL-Nasiriyah city in a Randomized Complete Block Design (RCBD) with three replications. In each replication each genotype was grown in a plot of 6 rows with a distance of $20 \mathrm{~cm}$ between two rows and the area of each experimental unit was $6 \mathrm{~m}^{2}$. Crop care was uniformly carried out for the experiment throughout the growing season. The soil was fertilized by the composite fertile $\left(100 \mathrm{~kg}^{\circ} \mathrm{ha}^{-1}\right)$ which was added at once through the tillage and Urea was used $(46 \% \mathrm{~N})$ at a rate of $200 \mathrm{~kg} \mathrm{~N} \mathrm{ha}^{-1}$ in three equal doses; the first dose was applied through sowing, the second dose was applied after tillering and the third at booting stage.

soil sample was taken from depth $0-20 \mathrm{~cm}$, contained $24 \%$ sand, $44 \%$ silt, $32 \%$ clay, alkaline $\mathrm{pH}$ of (7.72), total nitrogen (N) $0.62 \%$, available (Olsen) phosphorus (P) $0.51 \%$, available potassium cation $(\mathrm{K}) 1.24 \%$ and electrical conductivity 3.81 $\mathrm{dS} \mathrm{m}^{-1}$.The physico-chemical properties of the soil is presented in Table 2

Table 2. The physico-chemical properties of the site soil.

\begin{tabular}{lllllllll}
\hline Ions \% & \multicolumn{4}{c}{ Components \% } & \multirow{2}{*}{ EC des/m } & \multirow{2}{*}{ PH } & The type of Soil & traits \\
\hline $\mathbf{P}$ & $\mathbf{K}$ & $\mathbf{N}$ & clay & silt & sand & & The site \\
\hline 0.51 & 1.24 & 0.62 & 32 & 44 & 24 & 3.81 & 7.72 & Loamy-Clay \\
\hline
\end{tabular}

*these results were taken in Labor of water and soil in Agriculture Directorate of Dhi-Qar

\subsection{Statistical Analysis}

The analysis of variance (ANOVA) for the data collected for growth, yield and yield components was conducted by Genstat (Ver. 7.0) and correlation coefficients between each pairs of the traits computed by SPSS (Ver. 15.0). Means were separated using Fisher LSD.

\section{Results}

Results of the analysis variance of the studied traits showed (Tables 3and 4) that there were significant differences $(\mathrm{P}<0.05)$ between 10 wheat genotypes in almost traits which indicates that there was variation among the genotypes but there was no significant difference in some terms traits such the number of grains per spike and grain yield. This indicates that the studied genotypes are close to each other in terms of these traits.

The tallest wheat genotype was Synthetic $10(66.7 \mathrm{~cm})$, while the shortest one was Bohouth-22 $(51.0 \mathrm{~cm})$ and the mean plant height was $(59.2 \mathrm{~cm})$ Mahmood et al. [2006] obtained different results for wheat plant height from 62 to 110 $\mathrm{cm}$, while Aliu and Fetahu (2010) realized range 71 to $79 \mathrm{~cm}$ for plant height in different bread wheat genotypes.

The highest tillers number was American (8.33), while Sakha-93 and Synthetic 10 gave the lowest tiller number (3.67) without any significant difference between them and the mean tiller number was (4.80). The range of variations for number of spikes per square meter was between 212 and 365, related to cultivars Giza -11 and Egypt, respectively. The increased number of spikes per square meter is a reason for higher total 
dry matter production. Genotype Giza -11 displayed the highest spike length $(10.67 \mathrm{~cm})$ while genotype American showed lower spike length $(7.50 \mathrm{~cm})$ and the mean spike length was $8.60 \mathrm{~cm}$ under irrigated condition (Table. 3 ).

The results exhibited that the highest amount of relative number of grains per spike (NGS) was attributed to genotypes American (42.3), Giza -168 (40.3) and Giza -11 (38.3). The minimum amount of NGS was presented in Synthetic 10 and Synthetic 13 (31.0) without any significant difference between them .The mean grain number was 35.1(Table 4).

Genotypes Synthetic 10 and Sakha-93 showed the highest Spikes Weight per stem 1090, 1083 respectively, while Genotypes Giza-168 and Synthetic 38 gave the lowest Spikes Weight per stem 793, 747. The mean Spikes Weight per stem was 926 (Table 4).

The genotype Giza-11 gave the highest 1000-grains weight (46.6 g) while genotype Synthetic 10 exhibited the lower value for this trait $(27.0 \mathrm{~g})$. The mean thousand grains weight was $33.8 \mathrm{~g}$ (Table 4).

Grain yield ranged among the genotypes from 2.60 to 4.84 t.ha $^{-1}$. The highest grain yield was obtained from Egypt, American and Sakha-93 4.84, 4.66, 4.43 t.ha $^{-1}$ respectively, while genotypes Apa -99 and Synthetic-10 gave the lowest grain yield reached to $2.62,2.60$ t.ha $^{-1}$ respectively. The mean performance of grain yield was 3.58 t.ha ${ }^{-1}$.

Table 3. Analysis of variance of studied traits in irrigated condition.

\begin{tabular}{|c|c|c|c|c|}
\hline Geno. & PH & NT & NS & SL \\
\hline Egypt & $62.0 \mathrm{ab}$ & $4.67 \mathrm{ab}$ & a 365 & $7.83 \mathrm{~b}$ \\
\hline Sakha-93 & $57.0 \mathrm{ab}$ & $3.67 \mathrm{~b}$ & a 345 & $8.50 \mathrm{~b}$ \\
\hline Giza -11 & $65.2 \mathrm{a}$ & $4.33 \mathrm{~b}$ & c 212 & a 10.67 \\
\hline Giza -168 & $51.0 \mathrm{~b}$ & $4.00 \mathrm{~b}$ & abc 293 & b 8.17 \\
\hline Synthetic 10 & $66.7 \mathrm{a}$ & $3.67 \mathrm{~b}$ & ab 309 & ab 9.00 \\
\hline Synthetic 13 & $55.0 \mathrm{ab}$ & $4.00 \mathrm{~b}$ & a 338 & b 7.83 \\
\hline Synthetic 38 & a 64.3 & $4.33 \mathrm{~b}$ & bc 222 & b 8.67 \\
\hline Bohouth -22 & $51.0 \mathrm{~b}$ & $4.67 \mathrm{ab}$ & abc 287 & ab 9.33 \\
\hline Apa -99 & $57.5 \mathrm{ab}$ & $6.33 \mathrm{ab}$ & abc 282 & b 8.50 \\
\hline American & $\mathrm{ab} 62.3$ & a 8.33 & a 352 & b 7.50 \\
\hline Mean & 59.2 & 4.80 & 300 & 8.60 \\
\hline L.S.D at 0.05 & $11.90^{*}$ & $3.817^{*}$ & $94.6^{*}$ & $1.916^{*}$ \\
\hline C.V\% & 11.7 & 46.4 & 18.4 & 13 \\
\hline
\end{tabular}

* Significant at 5\% level of probability, KEY: PH: plant height $(\mathrm{cm}), \mathrm{NT}$ : Number of Tillers per plant, NS: Number of Spikes per square meter, SL: Spike Length $(\mathrm{cm})$.

Table 4. Analysis of variance of studied traits in irrigated condition.

\begin{tabular}{lllll}
\hline Geno. & NGS & SW & TGW & GY \\
\hline Egypt & 33.1 & ab 1017 & 39.3 ab & 4.84 \\
Sakha-93 & 34.5 & a 1083 & 36.1 bcd & 4.43 \\
Giza -11 & 38.3 & ab 857 & a 46.6 & 3.77 \\
Giza -168 & 40.3 & b 793 & bcd 31.7 & 3.82 \\
Synthetic 10 & 31.0 & a 1090 & d 27.0 & 2.60 \\
\hline
\end{tabular}

\begin{tabular}{lllll}
\hline Geno. & NGS & SW & TGW & GY \\
\hline Synthetic 13 & 31.0 & ab 833 & cd 28.7 & 2.97 \\
Synthetic 38 & 33.5 & b 747 & abc 37.5 & 2.84 \\
Bohouth -22 & 34.3 & ab 850 & bcd 31.7 & 3.22 \\
Apa -99 & 32.7 & ab 1005 & bcd 29.3 & 2.62 \\
American & 42.3 & ab 983 & bcd 30.6 & 4.66 \\
Mean & 35.1 & 926 & 33.8 & 3.58 \\
L.S.D at 0.05 & $12.36^{\text {NS }}$ & $285.5^{*}$ & $10.39^{*}$ & $2.307^{\text {NS }}$ \\
C.V\% & 20.5 & 18 & 17.9 & 37.6 \\
\hline
\end{tabular}

* Significant at 5\% level of probability, KEY: NGS: Number of Grains per Spike, SW: Spikes Weight per stem (g), TGW: 1000-grains weight (g), GY grain yield $\left(\mathrm{t} . \mathrm{ha}^{-1}\right)$.

\section{Correlation Analysis}

Simple correlation between different traits is reflected in Table 5 .

In this study grain yield showed positive and significant correlations with its components such as number of spikes per square meter $\left(\mathrm{r}=0.514^{* *}\right)$, spikes weight per stem $\left(\mathrm{r}=0.419^{*}\right)$ and it had a highly significant positive correlation with the number of grains per spike $\left(\mathrm{r}=0.647^{* *}\right)$ and 1000 -grains weight $\left(\mathrm{r}=0.582^{* *}\right)$. Therefore, these traits could be used as indirect criteria for the selection for high grain yield under supplemental irrigation condition. With increasing value of these traits, grain yield increases as well. Similar results had been reported by Ali et al. (2008) and Farzaneh (2013). Besides, There was non-significant positive correlation between plant height and grain yield $(r=0.209)$. Whereas, There were negative correlations indicated among grain yield with tillers per plant $(\mathrm{r}=-0.004)$ and Spike Length $(\mathrm{r}=-0.080)$. These results did not match the findings of Wang et al. (2001) who observed that genotypes with high spike had high yield in normal condition because of more photosynthetic capacity.

The yield components exhibited varying trends of association among themselves. Plant height revealed non-significant positive correlations to all traits but it showed negative correlation with Number of Tillers per plant $(\mathrm{r}=-0.074)$ and Number of Spikes per square meter $(\mathrm{r}=-0.030)$. Number of Tillers per plant had a positive non-significant correlation with Number of Grains per Spike $(r=0.179)$ and this finding is in agreement with Khan and Dar (2010). Whereas there was a negative non-significant correlation between Number of Grains per Spike and 1000 grain weight $(r=-0.179)$.Spike length exhibited positive association with spike weight and 1000 grains weight. El-Ameen et al. (2013) reported strong positive association among spike length, 1000 grain weight and number of grains per spike. There was positive non-significant between Number of Grains per Spike and 1000-grains weight $(\mathrm{r}=0.258)$.

Table 5. Simple Correlation coefficients between studied traits in bread wheat under normal conditions.

\begin{tabular}{|c|c|c|c|c|c|c|c|c|}
\hline Trait & PH & NT & NS & SL & NGS & SW & TGW & GY \\
\hline NT & -0.074 & & & & & & & \\
\hline NS & -0.030 & 0.083 & & & & & & \\
\hline SL & 0.117 & -0.085 & -0.281 & & & & & \\
\hline NGS & 0.155 & 0.179 & 0.089 & -0.185 & & & & \\
\hline SW & 0.358 & 0.140 & $0.615^{* *}$ & 0.170 & 0.157 & & & \\
\hline TGW & 0.351 & -0.179 & -0.239 & 0.303 & 0.258 & -0.054 & & \\
\hline
\end{tabular}




\begin{tabular}{lllllllll}
\hline Trait & PH & NT & NS & SL & NGS & SW & TGW & GY \\
\hline GY & 0.209 & -0.004 & $0.514^{* *}$ & -0.080 & $0.647^{* *}$ & $0.419^{*}$ & $0.582^{* *}$ \\
\hline
\end{tabular}

* and ** Significant at $\mathrm{p}<0.05$ and $<0.01$ respectively.

KEY: PH: plant height, NT: Number of Tillers per plant, NS: Number of Spikes per square meter, SL: Spike Length, NGS: Number of Grains per Spike, SW: Spikes Weight per stem, TGW:1000-grains weight, GY: grain yield.

\section{Discussion}

The grain yield, a major selection criterion, is a complex trait that determined by several physiological, biochemical and metabolic plant processes and its genetics and associations are greatly ambiguous (Ali et al., 2011). The traits such as plant height, number of spikes per square meter, number of grains per spike, spikes weight per stem and 1000-grains weight had positive correlations with grain yield, indicating its importance for selection and higher yields. This findings are in agreement with the findings of Gulmezoglu et al. (2010) who revealed that grain yield of wheat depended on plant height, length of spike and spike weight, but disagree with Dagustu (2008) who indicated significant and positive correlations between grain yield and spike length. De-Vita et al. (2007) reported that increasing number of seed per spike effect on the speed of photosynthesis, therefore, the potential produce of photosynthesis material increase and then yield increase.

The results of correlation coefficients, suggest that to increase grain yield under irrigated condition, more focus should be on morphological traits such as number of grains per spike and 1000-grains weight which have a high correlation with grain yield and also should utilize them as primary selection criteria for improving grain yield in wheat in normal well watered conditions. This result was also similar to research of Shamsi et al. (2011) who showed that the most important yield component on grain yield was 1000 grain weight. The influence of 1000 grains weight on grain yield seems to cause the fact that grains yield in wheat is frequently the sink limited (Fischer, 1985) and for this reason, the 1000 grains weight has been reported as a promising trait in increasing grain yield in wheat in irrigated conditions. The potential wheat grain yields at filling stage are dependent to limitation of sink and enlarging sink capacity can cause grain yield increasing.

\section{References}

[1] Ali Y., Atta B.M., Akhter J., Monneveux P., Lateef Z. 2008. Genetic variability, association and diversity studies in wheat (Triticum aestivum L.) germaplasm. Pak.J.Bot.40 (5):2087-2097.

[2] Ali M.A, Abbas A., Awan S.I., Jabran K., Gardezi S.D.A. 2011. Correlated response of various morpho-physiological characters with grain yield in sorghum landraces at different growth phases. J Animal Plant Sci 21(4):671-679.

[3] Aliu S. and Fetahu S. 2010. Determination on genetic variation for morphological traits and yield components of new winter wheat (Triticum aestivum L.) lines. Not. Sci. Biol. 2, 121-124.
[4] Akcura M. 2011. The relationships of some traits in Turkish winter bread wheat landraces. Turk. J. Agric. Forest. 35, $115-125$.

[5] Ashfaq M., Salamkhan A., Zulfiqar A. 2003. Association of morphological traits with grain yield in wheat (Triticum aestivum L.). Inter. J. of Agri. \& Biol. 5(3): 262-264.

[6] Atkinson M., Kettlewell P.S., Poulton P.R., Hollings P.D. 2008. Grain quality in the Broadbalk wheat experi-ment and the winter North Atlantic oscillation. J. Agric. Sci. 146, 541-549.

[7] Babak B., Ahmad B. 2015. Yield and yield components in bread wheat (Triticum aestivum L.) under non-stress and drought stress conditions. Int. J. Biosci. Vol. 6, No. 3, p. 338-348,

[8] Dagustu N. 2008. Genetic analysis of grain yield per spike and some agronomic traits in diallel crosses of bread wheat (Triticum aestivum L.). Turk J Agric For 32:249-258

[9] De-Vita P., Nicosia O.L.D., Nigro F., Platani C. 2007. Breeding progress in morpho-physiological, agronomical and qualitative traits of durum wheat cultivars released in Italy during the $20^{\text {th }}$ century. Eur. J. Agron. 26: 39-53.

[10] El Ameen T., Hossain A. and Teixeira da Silva J. A. 2013. Genetic

[11] analysis and selection for bread wheat yield and agronomic traits under drought condition. International J. Plant Breeding. 7 (1): 61-68.

[12] FAO, 2011. Food and Agricultural Organization of the United Nations, Rome, Italy. Available online at: http://faostat.fao.org

[13] Farzaneh P-Maragheh. 2013 . Investigate the relationship and path coefficient analysis between yield and its components in the number of winter wheat genotypes in the cold region of Ardabil. European Journal of Zoological Research, 2013, 2 (4):82-88 ISSN: 2278-7356.

[14] Fischer R.A. 1985. Number of kernels in wheat crops and the influence of solar radiation and temperature. J Agric Sci 105:447-461.

[15] Gulmezoglu N., Alpu O., Ozer E. 2010. Comparative performance of triticale and wheat grains by path analysis. Bulgar J Agric Sci 16 (4):443-453.

[16] Harlan J.R. 1998. Distributions of agricultural origins: A global perspective. Pages 1-2 in Origins of Agriculture and Crop Domestication. (A.B. Damania, J. Valkoun, G. Willcox, and C.O. Qualset, eds.), ICARDA, Aleppo, Syria

[17] Hawkes J.G. 1977. The importance of wild germplasm in plant breeding. Euphytica, 26: 615-621.

[18] Khan M.H. and A.N. Dar. 2010. Correlation and path coefficient analysis of some quantitative traits in wheat. African Crop Sci. J. 18(1): 9-14

[19] Khayatnezhad M., Zaefizadeh M., Gholamin R., jamaati-eSomarin S., Zabihi-e-Mahmoodabad R. 2010. Study of morphological traits of wheat cultivars through factor analysis. American-Eurasian J. Agric. \& Environ. Sci. 9 (5): 460-464. 
[20] Korkut K.Z., Baser I. and Bilgin O. 2001. Genotypic and phenotypic variability, heritability and phenotypic correlation for yield and yield components in bread wheat varieties. Acta Agronomica Hungarica, 49(3): 237-242.

[21] Mahmood Q., Lei W.D., Qureshi A.S., Khan M.R., Mayat I., Iilani G., Khan M.D. 2006. Heterosis correlation and path analysis of morphological and biochemical chatacters in wheat (Triticum aestivum L. Emp. Thell). Agric. J. 1(3), 180-185.

[22] Mohammadi M., Sharifi P., Karimizadeh R., Kazem M., Shefazadeh M.K. 2012. Relationships between grain yield and yield components in bread wheat under different water availability (dry land and supplemental irrigation conditions). Not. Bot. Hortic. Agro botany 40(1), 195-200.

[23] Mollasadeghi V., Elyasi S., Mirzamasoumzadeh B. 2012. Genetic variation of 12 bread wheat genotypes based on number of phonological and morphological traits. Ann. Biol. Res. 3, 4734-4740.
[24] Rosegrant M.W. and Agcaoili M. 2010. Global food demand, supply, and price prospects to 2010. International Food Policy Research Institute, Washington, D.C. USA

[25] Shamsi K., petrosyan M., Noor-mohammadi G., Haghparast A., Kobraee S., Rasekhi B. 2011. Differential agronomic responses of bread wheat cultivars to drought stress in the west of Iran. Afr. J. Biotechnol. 10(14): 2708-2715.

[26] Tian J.C.,Dend Z.Y.,Hu R.B., Wang Y.X. 2012. Yield components of super wheat cultivars with different types and the path coefficient analysis on grain yield.Acta Agron. Sin,(11):1699-1705.

[27] Wang Z.M., Wei A.L., Zheng D.M. 2001. Photosynthetic characteristic of non leaf organs of winter wheat cultivar differing in ear type and their relationship with grain mass per ear. Photosynthetica. 39: 239-244. 